\title{
Using transitivity Analysis to Reveal the Nature of Characters in Louisa May Alcott's Little Women
}

\author{
Noah Napare Emayakre \\ ORCID: https://orcid.org/0000-0002-2048-6496 \\ Department of Languages \\ Bagabaga College of Education, Ghana
}

Corresponding Mail: noahnapare@gmail.com

\begin{abstract}
Copyright resides with the author(s) in terms of the Creative Commons Attribution CC BY-NC 4.0. The users may copy, distribute, transmit and adapt the work, but must recognize the author(s) and the East African Journal of Education and Social Sciences
\end{abstract}

\begin{abstract}
This article used transitivity analysis to reveal the nature of four major characters in Playing Pilgrims, a short story in Louisa May Alcott's Little Women. The four major characters in the story are: Jo, Meg, Beth and Amy. The items in the novel are classified into three main components of transitivity. The main components are Participant, Circumstance and Process but the focus of analysis was on process type. The process types assigned to each character was countered and tabulated percentage wise. It was established that the author used 233 process types in the story. The study established that transitivity analysis could be used to analyze or reveal the nature of characters in a story depending on the type of processes assigned to those characters in the story. Meg is the most emotional character in the story since she was assigned the highest number of mental process. Jo is the most sociable character in the story as she was assigned the highest number of relational process. Amy, on the other hand, is the most physically active character since she was assigned the highest number of material process. On the other hand, Jo can be seen as the most vocal character in the story since she was assigned the highest number of verbal process which focuses on the vocal ability of a character. Beth is the character who exhibited most of the behavioral attitudes in the story. Existential process was not assigned to any of the major characters in the short story. The study recommends that researchers who may have interest in transitivity analysis should use it to analyze other works of Louisa May Alcott to establish whether their findings would be similar to the findings of this study or different.
\end{abstract}

Keywords: Transitivity; process types; Characters; Playing Pilgrims; Participant; Circumstance.

How to cite: Emayakre, N. N. (2021).Using transitivity Analysis to Reveal the Nature of Characters in Louisa May Alcott's Little Women. East African Journal of Education and Social Sciences 2(4), 146-150. Doi: https://doi.org/10.46606/eajess2021v02i04.0139.

\section{Introduction}

Authors carry their messages across to readers in stories through characters. For this reason, for the reader to be able to understand the story, he or she is supposed to link the message in the text with the actions of the characters since the actions contribute immensely towards the development of the plot in the story. To be able to understand the story, the reader needs to consider the actions of the characters and their relationship with other characters in the story.

Songni (2019) analyzed the "Little Women" from the perspective of Western Humanism and revealed that humanism is a situation which common people can reach just as the four main characters: Jo, Beth, Amy and Meg were able to make it in life even though they started from a very poor background. In another instance, Bartleby (2017) used an essay to analyze the social behavior of characters in the 
novel. The writer analyzed the emotional attitude of the main characters and it was revealed that Jo was a violent and temperamental character. Beth was an excellent pianist and had to overcome her shyness while Amy was an artistic beauty character who was good at manipulating other people to get what she wanted. Meg was a lovely and caring character who dedicated most of her time for her family. According to Kendall (2017), the novel plays with emotions and the tone is calm. With regard to the character behavioral analysis, Jo was more lady-like, Meg was a character that had high self-esteem, Beth was a shy character and Amy had to overcome her aristocratic pride. Kavana(2019) lamented that the characters were imperfect, varied and were rather unstable. Meg was a tender and beautiful character. Jo was rebellious and free-spirited character who would not care about the norms of the society but loved her family dearly. Amy was an artist and a little selfish character while Beth was a delicate and kind hearted character who did not have any expectation about the future.

From the analysis, none of the writers used the process types to analyze the nature of characters in the novel "Little Women." This prompted the researcher to conduct this study, using transitivity analysis to reveal the nature of characters in Louisa May Alcott's Little Women.

\section{Background of the Novel}

Little Women was written in America by Louisa May Alcott during the American Civil War and was first published in 1979. The novel is about four sisters: Jo, Meg, Beth and Amy who were growing up in a poor family at the time of the Civil War. The novel contains 19 stories. This study uses the process analysis approach to establish the nature of the four main characters in the first story of the novel, entitled Playing Pilgrims.

\section{Theoretical work on the Novel}

Little Women has received a number of commentaries and criticisms. For instance, Delphine (2008/2009) worked massively on the theme: "Love and Marriage." He presented a technique that Alcott employed in bringing the theme into picture. He poured out his innermost thanks and gratitude to the author for her achievement: "Indeed, Louisa May Alcott has been studied, examined and praised by many feminist critics for her feminist writing. Her writing influenced a great number of female writers and intellectuals. While it was accepted as an
American classic in the 1950s, its influence should not to be underestimated.

MacDonald (1985) wrote an essay on the caption: "Who is still Reading Miss Alcott and Why." By her subject matter in the essay, she praises Alcott for her good effort and refutes the idea that Alcott's Little Women is a sentimental and a romantic novel as some critics look at it. According to her, Alcott's message in the novel is real and is not a romantic fiction. "MacDonald contrasts recent responses to Little Woman with those of child readers in Alcott's time, suggesting that although modern critics often consider the book sentimental and romantic, when compared to other works of the time, it is radical and realistic."

\section{Review of the related literature Transitivity}

In grammar, transitivity is a term used to describe whether a verb takes a direct or indirect object in a sentence. When a verb takes a direct object, it is known as transitive verb. On the other hand, when a verb does not take a direct object, it is called an intransitive verb. A situation whereby a verb takes both direct and indirect object, such a verb is known as a ditransitive verb. Further, there is another instance where a verb could be used transitively or intransitively in a sentence construction. A verb which falls within this umbrella is known as ambitransitive verb. In functional grammar, transitivity as a concept is seen and perceived in different dimensions. In functional grammar, transitivity simply talks about the transfer of actions from a participant to the other in the clause. The entity that undertakes the action is called the participant. The action in the clause is the process while the geographical space where the action takes place is the circumstance. According to Halliday (2004, p.125), transitivity as a grammatical concept is defined as one that "consists of a flow of events."

All figures consist of a process unfolding through time and of participants being directly involved in some way. In addition, there may be circumstances of time, space, cause, manner or one of a few other types. These circumstances are not directly involved in the process; rather they are attendant on it. All such figures are sorted out in the grammar of the clause. The clause is also a mode of reflection and of imposing order on the endless variation and flow of events. The grammatical system by which this is achieved is transitivity. 
According to Halliday and Matthiessen (2004), transitivity as a grammatical concept basically refers to the transfer of action and its consequences from one participant to another participant. In transitivity, there is always somebody/ something carrying out an action in the clause. The entity carrying out the action in the clause is known as participant. The action carried out by the participant in the clause is called the process and the space within in which the action takes place is the circumstance.

\section{Characters}

Characters are the entities that take actions in a story. They could be humans, animals, trees or ideas who are assigned action roles in a story. Writers use characters to develop a plot in the story in order to achieve their intended purpose. A character could be main or minor. The main character takes active role while a minor character takes a passive role in the story. A story can have one character which is known as a protagonist.

According to Kelly (2002), a character can be dynamic or static. A dynamic character changes as the story unfolds but a static character, on the other hand, does not change in the course of the story. Another category of characters is called round character. Round characters are complex beings. They feel more like people and they are multidimensional in nature.

\section{Major Components of Transitivity}

Transitivity has three main components. These components interact in an organized manner in the clause to achieve the purpose of the expression. The components are: participant, process and circumstance.

\section{Participant as a Component of Transitivity}

Participant is a nominal aspect which is directly or indirectly involved in the action taken by the verb in the clause. It is the entity that takes an action in the clause. Participant as an entity has different semantic roles in the clause which could be agent, patient, theme, experiencer, beneficiary, instrument, goal, source, stimulus or force.

\section{Process as a component of Transitivity}

This refers to the verbal segment of the clause. Through this verbal segment, the action unfolds in the clause.

\section{Circumstance as a component of Transitivity}

Circumstance as a component of transitivity refers to the geographical space within which the action of the clause takes place. Examples include: where, in the room, how, when, behind and there.

\section{Types of process as a component of Transitivity}

Within process as a component of transitivity, there are sub-categories which are briefly explained below.

Material Process: This process type refers to doing and happening. Here action verbs such as go, throw, sing, cut, kick, eat and write are used.

Mental Process: This process type tells us that there is the act of sensing a phenomenon in the clause. Such verbs as like, afraid, feel, scare and frighten fall within the mental process.

Relational Process: Relational process as a subcategory of process type tells us that there are elements of being and having in the clause. Some of the verbs used here include: is, are, were, was and am.

Existential Process: This process type tells us that there is an existence of something or somebody in the clause. Some of the verbs used here are: is, was and are.

Behavioral Process: This process type tells us that an entity shows some kind of psychological behavior in the clause. Some of the verbs used here are: to be lazy, to be kind, to be afraid, to be stupid and to be hard-working.

Verbal Process: In this type of process, there is an act of 'saying' in the clause. Some of the verbs used are: to say, to confirm, to call, to reject and to speak.

\section{Methodology}

The study used descriptive research design to study how transitivity as a concept could be used to reveal the nature of characters in the story.

\section{Focus of Analysis}

Focus of analysis was on the type of processes used in the short story. It was revealed that all the six type of processes (mental process, material process, relational process, verbal process, behavioral process and existential process) were used in the story. However, no major character was assigned to existential process.

Clauses in the story were divided into three main components of transitivity. After that, every type of process in the story was counted and recorded accordingly. 


\section{Findings}

It was found out that the author used a total number of 213 clauses in the story. It was also establish that 233 process types were used in the story.

After going through the classification of the type of processes used in the story, it was established that even though the author used all the six types of processes, the author used a total number of 233 process types in the story but no major character was assigned to the existential process.

Statistically, mental process occurred 46 times representing $19.74 \%$, relational process occurred 51 times representing $21.89 \%$, material process occurred 106 times giving the material process $45.49 \%$.

The verbal process which talks about the oral interactions of the characters in the story occurred 17 times which represents $7.3 \%$. The behavioral process appeared 11 times and this gives it $4.72 \%$. In the final analysis, existential process which has not been assigned to any of the major characters appeared only 2 times giving it $0.86 \%$.

\section{A detailed Character Analysis}

Mental Process: A total number of 36 mental process types were assigned to the major characters. Out of this number, 17 process types representing $47.22 \%$ was assigned to Meg. Ten processes representing $27.78 \%$ went to Jo. Amy took 8 processes representing $22.22 \%$ and finally Beth took one process representing $2.78 \%$. From the analysis, Meg is seen as the most emotional character in the story since she was assigned the highest number of mental process which reveals the emotional attitude of a character.

Relational Process: A total number of 34 relational process types were assigned to the major characters in the story. Out of this number, 18 process types representing 52.94\% went to Jo. Meg took 6 process types representing 17.65\%. Beth took 6 process types representing $17.65 \%$ and 4 process types representing $11.76 \%$ went to Amy. Therefore, Jo is seen as the most sociable character in the story as she was assigned the highest number of relational process which focuses on how characters relate to one another and other events in the story. This follows by Meg and Beth at the same magnitude and finally, Amy.
Material Process: A total number of 98 material processes were assigned to the major characters. Out of this number, 48 processes representing $48.97 \%$ went to Amy, 22 representing $22.45 \%$ was taken by Meg, 17 representing $17.35 \%$ went to Jo and 11 processes representing $11.22 \%$ went to Beth. Therefore, Amy is seen as the most physically active character since she was assigned the highest number of material process.

Verbal Process: In the short story, 14 verbal processes were assigned to the major characters. Out of this, 8 processes representing $57.14 \%$ went to Jo, 3 representing $21.44 \%$ went to Meg, 2 representing $14.29 \%$ went to Amy and 1 representing $7.14 \%$ went to Beth. Therefore, Jo can be seen as the most vocal character in the story since she was assigned the highest number of verbal process which focuses on the vocal ability (words) of a character.

Behavioral Process: A total number of 9 behavioral processes were assigned to the major characters. Out of this number, 4 processes representing $44.45 \%$ went to Beth, 2 processes representing $22.22 \%$ went to Amy, 2 processes representing $22.22 \%$ went to $\mathrm{Meg}$ and 1 process representing $11.11 \%$ went to Jo. Therefore, Beth is the character who exhibited most of the behavioral attitudes in the story.

Existential Process: It was observed that existential process was not assigned to any of the major characters in the short story.

\section{Conclusions and Recommendations Conclusions}

It is concluded that transitivity analysis could be used to analyze or reveal the nature of characters in a story depending on the type of processes assigned to those characters in the story. From the analysis, Meg is the most emotional character in the story since she was assigned the highest number of mental process. Jo is the most sociable character in the story as she was assigned the highest number of relational process which focuses on how characters relate to one another and other events in the story. Amy, on the other hand, is the most physically active character since she was assigned the highest number of material process. On the other hand, Jo can be seen as the most vocal character in the story since she was assigned the highest number of verbal process which focuses on the vocal ability (words) of a character and Beth is the character who exhibited most of the behavioral attitudes in the story. 
Existential process was not assigned to any of the major characters in the short story.

\section{Recommendations}

The study recommends that researchers who may have key interest in transitivity analysis should use it to analyze other works of Louisa May Alcott to establish whether their findings would be similar to the findings of this study or different.

\section{References}

Bartleby S. (2017). Analysis of Little Women by Louisa May Alcott. Unpublished Essay, USA.

Delphine L. (2008/2009/). Little Women, a Feminist study: Master Degree, Unpublished Thesis, Ghent University.

Halliday, M. A. K. (2004). An Introduction to Functional Grammar (2nd ed). London: Edward Arnold.
Halliday, M. A. K. and Matthiessen, C. M. I. M. (2004). An Introduction to Functional Grammar (3rd ed).London: Edward Arnold.

Kavana V. V. (2019). Analysis of Little Women and why I think separating Jo and Laurie was its biggest blunder. Unpublished Essay, U S A.

Kelly, G. (2002). Writing Essays about Literature: A Guide and Style Sheet (6th ed). USA.

KendallL.(2017). Novel Analysis. Unpublished Essay, USA.

Macdonald R. K. (1985). 'Who is still Reading Miss Alcott and Why?' Unpublished Essay, USA.

Songni ,Z. (2019). Analysis of Little Women from the Perspective of Western Humanism. Atlantic Press, Paris. 